\title{
A cross-sectional study of cryptorchidism in children: testicular volume and hormonal function at 18 years of age
}

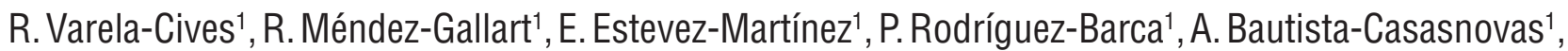 \\ M. Pombo-Arias², R. Tojo-Sierra²
}

${ }^{1}$ Department of Pediatric Surgery \& Urology, University Hospital of Santiago, Santiago de Compostela, Spain; ${ }^{2}$ Department of Pediatrics, University Hospital of Santiago, Santiago de Compostela, Spain

\begin{abstract}
Purpose: To evaluate the relationship between unilateral or bilateral criptorchidism, patient age, primary location of the gonad and modality of treatment with testicular volume and hormonal status at 18 years in patients diagnosed and treated for cryptorchidism during childhood.

Materials and Methods: Testicular volume, LH, FSH, and testosterone were evaluated in 143 young men at 18 years treated in childhood for unilateral $(n=103)$ or bilateral $(\mathrm{n}=40)$ cryptorchidism.

Results: Unilateral cryptorchidism: Location of testis was prescrotal in 36 patients, inguinal in 52 and non-palpable in 15. The mean volume was $9.7 \mathrm{~mL}$ compared to 16.2 $\mathrm{mL}$. for the spontaneously descended testicle in unilateral cryptorchidism. However, 22 patients who received HCG had a significantly bigger testis (11.8 $\mathrm{mL}$.) than those treated with primary surgery $(9.2 \mathrm{~mL})$. The results showed a significant positive correlation between testicular volume and patient age at treatment.

Bilateral cryptorchidism: Location of testis was prescrotal in 34 cases, inguinal in 40 and 6 patients with non-palpable testicles. Mean volume at 18 years was $12.9 \mathrm{~mL}$, greater than unilateral cryptorchid testis $(9.7 \mathrm{~mL})$ but smaller than healthy contralateral in unilateral cases $(16.2 \mathrm{~mL})$. There were significant differences in the testicular growth for bilateral patients with testicular descent after being treated with HCG (14.4 mL) in respect with those untreated $(11.1 \mathrm{~mL})$ or those who underwent primary surgery (11.4 $\mathrm{mL}$ ). There was a significant positive correlation between the testicular volume and palpable $(12.4 \mathrm{~mL})$ or non-palpable testis $(10.4 \mathrm{~mL})$. There was a correlation between unilateral or bilateral cryptorchidism and levels of FSH.

Conclusions: Testicular volume and hormonal function at 18 years for patients diagnosed and treated for cryptorchidism during childhood are strongly influenced by whether the undescended testis was unilateral or bilateral. Location of the testes at diagnosis or age of initial treatment exerts no definite effect on testicular volume improvement or hormonal levels at 18 years of age.
\end{abstract}

\section{ARTICLE INFO}

\section{Key words:}

Cryptorchidism; growth hormone releasing hormonerelated peptide [Supplementary Concept]; Estrogen Replacement Therapy; Orchiopexy

Int Braz J Urol. 2015; 41: 57-66

Submitted for publication: August 13, 2013

Accepted after revision: June 01, 2014

\section{INTRODUCTION}

Incomplete descent of one or both testicles from the abdominal cavity, through the inguinal canal into the scrotum (cryptorchidism) is a multifactorial etiology abnormality that affects $1-1.8 \%$ of male infants (1). It is reported to be associated with infertility and testicular cancer (2). To minimize these complications is mandatory the placement and fixation of the testis in 
the scrotum $(2,3)$. It is not known the ideal age for surgical treatment and which is the ideal therapy (4). However, based on several studies that show that undescended testes undergo early and progressive deterioration, the recommended age for treatment has been decreasing gradually as we have improved our understanding of spermatogenesis $(3,5)$.

Testicular damage may be secondary to the abnormal position of the testis. This damage is basically characterized by a progressive reduction in germ cell number and size of the seminiferous tubules with peritubular fibrosis and hyalinization, resulting in a decrease of the number of Leydig cells. These facts may affect the production of sexual hormones promoting testicular atrophy with subsequent infertility (6-8). Hence, the testicular volume and hormone levels are related to reflect the spermatogenesis and are considered to be indirect indicators to predict the potential for fertility. (9-11). But it is also possible that the undescended testis has been inherently atrophic (12-14); therefore, early correction of cryptorchidism would be less important (15-17).

A cross-sectional observational transverse study was performed to evaluate the relationship between age at treatment, location of the gonad and type of treatment (hormonal and/or surgical therapy) on testicular growth and hormonal function at 18 years of age in patients treated for unilateral or bilateral cryptorchidism during childhood. To the best of our knownledge, this is the first reported survey of longitudinal long-term follow-up of patients with cryptorchidism.

\section{PATIENTS AND METHODS}

\section{Study population}

The study population consisted of 143 boys who were born before 1993 and were diagnosed as having unilateral (103 cases) or bilateral (40 patients) primary cryptorchidism. Patients with retractile testis, endocrine diseases, chromosomal abnormalities, incomplete data or dysmorphic features were excluded from the study. The mean age at effective treatment was $7.42 \pm 3$ years. All these patients were evaluated at 18 years of age and divided in two separate groups: unilateral and bilateral cases.

\section{DESIGN OF THE STUDY AND FOLLOW-UP DATA}

\section{Design of study}

A cross-sectional observational transverse study at 18 years of age of boys diagnosed and treated of unilateral or bilateral cryptorchidism during infancy and/or childhood period.

\section{Physical examination}

Physical examination included assessment of testis position obtained by gentle manipulation. Testis position was classified as pre-scrotal (between external inguinal ring and scrotum), inguinal, or nonpalpable. Testicular volume was measured using a Prader orchidometer (a chain with 13 numbered beads of increasing size from 1 to $30 \mathrm{~mL}$ ).

\section{Testicular ultrasound}

After the physical examination, testicular volume was measured with ultrasonography at 18 years of age. All ultrasound examinations were performed with a $12-\mathrm{MHz}$ linear transducer. To measure the testicular volume, the scanner was placed on the inguinal region or on the scrotum. Three separate transverse and longitudinal images were recorded for each testis to assess the volume. After maximum length, width and height were obtained in the ultrasound, the testicular volume was calculated using the empiric formula of Lambert first described in 1951. The Lambert equation (length $\mathrm{x}$ width $\mathrm{x}$ height $x$ 0.71) estimates the ellipsoid testicular volume more accurately. The testicular volume estimated by Prader orchidometry correlated closely with the measurements by ultrasonography (18).

\section{Surgical and/or hormonal therapy}

According to the protocol established in our hospital, hormonal therapy was offered to all cases as first line treatment. Boys who accepted were given human chorionic gonadotropin hormone (HCG) intramuscularly twice a week for five weeks. Each injection was 250 IU for children under two years, $500 \mathrm{IU}$. for children between 2 and 6 years, and 1,000 IU for ages 6 to 11 years, following the recommendations of the expert group of WHO in cryptorchidism (19). Patients 
who refused or did not respond to hormonal treatment, underwent surgery for correction of undescended testes according to the standard surgical orchidopexy technique (20). Effective age of treatment was considered once the testis was definitely located in the scrotum after hormonal and/or surgery.

\section{Follow-up}

All patients were followed at the outpatient clinic in the first year at one, 3, 6 and 9 months after treatment (medical or surgical). Then, they were reviewed annually until age 18 . At the age of 18, a physical examination was performed in all patients, checking the location of the testes and their size using a Prader orchidometer. True testicular volume was determined by ultrasonography and the empiric formula of Lambert. One pediatric surgeon (RVC) performed more than 95\% of the clinical examinations. Blood samples were analyzed in all adolescents for FSH, LH and Testosterone levels. Hormonal levels were measured using an immunometric monoclonal assay. Semen analysis was realized only in a small number of adolescent's patients who voluntary provided a semen specimen after ejaculation. Patients were definitely discharged once informed of the laboratory results and concerns about potential of fertility and risk of testicular malignancies.

\section{Statistical analysis}

The mean, median, and range were calculated using standard methodology. Data were reported as means when normally distributed, and medians when non-normally distributed. Categorical variables are presented as absolute numbers and percentages, continuous variables as means, standard deviations, minimum and maximum range. Means were compared using the chi-squared or Fisher exact test and medians were compared using the non-parametric Mann-Whitney U test. Differences in proportions among categoric data were assessed using the Fisher exact test. All data were analysed by the statistical package SPSS for Windows, version 18.0 (SPSS, Chicago, IL, USA). Statistical significance was set at $\mathrm{p}<0.05$.

\section{ETHICAL APPROVAL}

The Local Ethical Committee of the University Hospital of Santiago de Compostela, Spain approved the study. Informed consent was obtained from all parents of the patients who agreed to participate in the study.

\section{RESULTS}

The mean age at referral for undescended testis was 7.42 years (range 1-13). Of the 143 boys diagnosed with undescended testis, the anomaly was bilateral in 40 and unilateral in the remaining 103. Of these 103 boys, the anomaly was on the left in $45(43.7 \%)$ and on the right side in the remaining 58 (56.3\%). In all cases the testicular volume was measured by Prader orchidometry and ultrasonography.

\section{Unilateral Cases}

Among unilateral cases (Table-1) only 15 patients had non-palpable testis (14.5\%) and 88 had a palpable gonad. Of these 103 unilateral patients, 26 patients refused hormone treatment. Treatment with HCG induced the descent in 22 testes $(28.6 \%)$ for a total of 77 patients. The descent of those located in the inguinal region was $3 / 39(7.7 \%)$ and $19 / 32(59.4 \%)$ of those located high scrotal. Unilateral non-palpable testis in patients who received HCG therapy did not respond (0/5). We performed an orchidopexy in 81 patients with unilateral disease, 26 primary and 55 subsequent to failure of medical treatment. In $20 \%$ (3/15) of non-palpable unilateral cases, a very atrophic testicle was found during the surgical procedure. The volume of undescended testicle in unilateral cases was significantly smaller in size (median $9.7 \mathrm{~mL}$ ) than its counterpart normal testicle (median $16.2 \mathrm{~mL}$ ). The hormone levels were within normal ranges in all cases, mean $4.01 \mathrm{IU} / \mathrm{L}$ for FSH, $4.32 \mathrm{IU} / \mathrm{L}$ for $\mathrm{LH}$ and $6.75 \mathrm{ng} /$ $\mathrm{mL}$ for testosterone. Testicular volume of patients with scrotal descent after HCG treatment (22 cases) was significantly higher (mean $11.8 \mathrm{~mL}$ ) in respect to those who were operated after failure of hormonal therapy (mean $9.2 \mathrm{~mL}$.) and those who underwent primary surgery (mean $8.6 \mathrm{~mL}$ ) 
Table 1 - Unilateral cryptorchidism $(n=103)$. Features based on testis location and therapy used (A-only hormonal treatment; B-hormonal first and surgery later; CX - surgery alone; TEST-Testosterone).

\begin{tabular}{|c|c|c|c|c|c|c|c|c|}
\hline \multirow{4}{*}{$\begin{array}{l}\text { Treatment } \\
\text { Groups }\end{array}$} & \multicolumn{8}{|c|}{ Testis Location } \\
\hline & \multicolumn{3}{|c|}{ Pre-Scrotal (36) } & \multicolumn{3}{|c|}{ Inguinal (52) } & \multicolumn{2}{|c|}{ Non Palpable (15) } \\
\hline & \multicolumn{2}{|c|}{ Hormonal therapy } & \multirow[t]{2}{*}{$c x$} & \multicolumn{2}{|c|}{ Hormonal therapy } & \multirow[t]{2}{*}{$c x$} & $\begin{array}{l}\text { Hormonal } \\
\text { Therapy }\end{array}$ & \multirow[t]{2}{*}{$c x$} \\
\hline & A & B & & A & B & & A & \\
\hline Patients & 19 & 13 & 4 & 3 & 36 & 13 & 0 & 9 \\
\hline FSH (UI/L) & 3.6 & 3.9 & 3.8 & $4.9\left(^{*}\right)$ & 3.7 & 4.4 & 4.03 & 3.8 \\
\hline Range & $(1.7-7.6)$ & $(3.3-8.8)$ & $(2.5-6.0)$ & & $(2.6-5.9)$ & $(2.3-9.2)$ & $(3.4-4.6)$ & $(2.3-8.4)$ \\
\hline LH (UI/L) & 3.5 & 5.9 & 4.7 & $6.2\left(^{*}\right)$ & 3.8 & 3.3 & 3.93 & 3.25 \\
\hline Range & $(3.1-5.5)$ & $(2.6-7.5)$ & $(3.4-5.8)$ & & $(2.8-5.1)$ & $(2.8-5.4)$ & $(3.1-4.6)$ & $(2.7-4.3)$ \\
\hline TEST. (Ng/mL) & 5.2 & 5.4 & 6.1 & $10.1\left(^{*}\right)$ & 6.3 & 5.6 & 10.0 & 5.3 \\
\hline Range & $(4.8-9.1)$ & $(4.1-6.8)$ & $(5.3-9.8)$ & & $(5.2-8.1)$ & $(4.5-6.6)$ & $(4.6-18.2)$ & $(3.9-11.9)$ \\
\hline $\begin{array}{l}\text { Age Treatment } \\
\text { (months) }\end{array}$ & 84.6 & 98.7 & $140.7^{*}$ & $121.2\left(^{*}\right)$ & 92.6 & 81.1 & 57.9 & 87.5 \\
\hline Range & $(44.1-99.5)$ & $(53.5-137.3)$ & $(131-143)$ & & $(37.2-137)$ & $(30.4-140.0)$ & $(28.7-99.7)$ & $(71.5-113.4)$ \\
\hline \multicolumn{9}{|l|}{ Testicular Vol. } \\
\hline Affected testis & $\begin{array}{c}13.0 \\
(10.0-17.8)\end{array}$ & $\begin{array}{c}11.3 \\
(7.8-22.6)\end{array}$ & $\begin{array}{c}9.4 \\
(8.8-10.2)\end{array}$ & $\begin{array}{c}10.7 \\
(7.8-12.5)\end{array}$ & $\begin{array}{l}10.1^{* * * *} \\
(7.3-13.0)\end{array}$ & $\begin{array}{c}11.9 * * \\
(8.05-14.4)\end{array}$ & $\begin{array}{c}6.3^{\star *} \\
(0.1-9.1)\end{array}$ & $\begin{array}{c}4.6 * * * \\
(0.1-10.5)\end{array}$ \\
\hline $\begin{array}{l}\text { Non affected } \\
\text { testis }\end{array}$ & $\begin{array}{c}13.5 \\
(10.5-18.0)\end{array}$ & $\begin{array}{c}16.7 \\
(13.1-22.1)\end{array}$ & $\begin{array}{c}9.8 \\
(8.3-12.3)\end{array}$ & $\begin{array}{c}22.9 \\
(11.0-24.3)\end{array}$ & $\begin{array}{c}14.8 \\
(11.8-18.5)\end{array}$ & $\begin{array}{c}15.8 \\
(11.9-21.3)\end{array}$ & $\begin{array}{c}16.4 \\
(10.3-23.7)\end{array}$ & $\begin{array}{c}19.7 \\
(16.0-30.6)\end{array}$ \\
\hline
\end{tabular}

${ }^{*}$ ) Only 1 case with data

${ }^{*} \mathrm{p}<0.05 ;{ }^{* *} \mathrm{p}<0.01 ;{ }^{* * *} \mathrm{p}<0.005 ;{ }^{* * * *} \mathrm{P}<0.001$

$(\mathrm{p}=0.019)$. However, hormone levels were similar in all groups without any statistically significant differences.

In this survey, testicular volume of the palpable testes was significantly greater than non-palpable ones (mean $11.0 \mathrm{~mL}$ vs. $7.6 \mathrm{~mL}$ ). However, volume of the contralateral testes was significantly lower in the group of palpable testes. Thus, the total testicular volume (ie, sum of the volumes of both testes estimated by Lambert's equation or Prader orchidometry) in both groups of patients related to unilateral criptorchidism (palpable and non-palpable) was similar. In patients with retained testicles in the inguinal position, the volume was significantly lower in respect to its counterpart, regardless of type of treatment. No differences in hormone levels according to the situation of the gonad were noticed (Table-1). In boys treated before 2 years of age (Table-2) there was a further development of both the undescended testicle (median $13.4 \mathrm{~mL}$ ) and healthy scrotal counterpart (median $17.1 \mathrm{~mL}$ ) in respect to the patients treated after 2 years of age (11.0 mL and $14.7 \mathrm{~mL}$ respectively). However, FSH, LH and testosterone levels did not show statistically significant differences in these two groups of patients.

\section{Bilateral Cases}

In patients with bilateral cryptorchidism (Table-3) 6 cases had non-palpable testes but 74 had palpable ones. Of all bilateral cases, 5 pa- 
Table 2 - Unilateral cryptorchidism ( $\mathrm{n=103)}$ Features based on age and therapy (A-only hormonal treatment; $B$-hormonal first and surgery later; CX - surgery alone; TEST-Testosterone).

\begin{tabular}{|c|c|c|c|c|c|c|c|c|c|}
\hline & \multicolumn{3}{|c|}{$<2$ years } & \multicolumn{3}{|c|}{ 2-6 years } & \multicolumn{3}{|c|}{$>6$ years } \\
\hline & \multicolumn{2}{|c|}{ Hormonal therapy } & \multirow[t]{2}{*}{$c X$} & \multicolumn{2}{|c|}{ Hormonal therapy } & \multirow[t]{2}{*}{$c X$} & \multicolumn{2}{|c|}{ Hormonal therapy } & \multirow[t]{2}{*}{$C X$} \\
\hline & A & B & & $A$ & B & & $A$ & B & \\
\hline FSH (UI/L) & $4.0\left(^{*}\right)$ & 3.5 & $5.3\left(^{*}\right)$ & 2.3 & 4.1 & 3.5 & 4.0 & 3.8 & 3.8 \\
\hline Range & & $(2.5-5.4)$ & & $(1.1-7.0)$ & $(2.5-5.7)$ & $(2.2-8.0)$ & $(2.0-9.5)$ & $(3.2-6.3)$ & $(2.5-7.6)$ \\
\hline LH (UI/L) & $2.8\left(^{*}\right)$ & 4.2 & $2.7\left(^{*}\right)$ & 3.2 & 4.8 & 3.1 & 5.1 & 3.8 & 3.5 \\
\hline Range & & $(3.3-5.6)$ & & $(3.2-3.5)$ & $(2.9-5.9)$ & $(2.9-3.3)$ & $(3.2-6.1)$ & $(2.7-5.1)$ & $(3.3-5.8)$ \\
\hline TEST (Ng/mL) & $4.9\left(^{*}\right)$ & 7.5 & $5.6\left(^{*}\right)$ & 6.7 & 5.9 & 4.6 & 5.2 & 5.9 & 6.0 \\
\hline Range & & $(5.5-16.6)$ & & $(5.3-9.9)$ & $(4.4-8.2)$ & $(3.8-6.6)$ & $(4.8-10.1)$ & $(4.8-7.8)$ & $(4.5-9.1)$ \\
\hline $\begin{array}{l}\text { Age at treatment } \\
\text { (months) }\end{array}$ & $\begin{array}{c}11.9 \\
(8.6-15.7)\end{array}$ & $\begin{array}{c}18.3 \\
(14.5-21.3)\end{array}$ & $\begin{array}{c}17.8 \\
(17.3-20.1)\end{array}$ & $\begin{array}{c}37.2 \\
(27.5-60)\end{array}$ & $\begin{array}{c}50.1 \\
(34.2-54)\end{array}$ & $\begin{array}{c}36.0 \\
(28.5-59)\end{array}$ & $\begin{array}{c}96.2 \\
(80.5-121)\end{array}$ & $\begin{array}{c}80.9 \\
(46.3-126)\end{array}$ & $\begin{array}{c}128.7^{\star} \\
(87.6-142)\end{array}$ \\
\hline \multicolumn{10}{|l|}{ Testic. Volume } \\
\hline Affected testis & $\begin{array}{c}17.2 \\
(11.4-23.0)\end{array}$ & $\begin{array}{c}11.2 \\
(9.3-13.5)\end{array}$ & $\begin{array}{c}11.9 \\
(0.1-15.0)\end{array}$ & $\begin{array}{c}15.4 \\
(11.8-18)\end{array}$ & $\begin{array}{c}8.3^{* \star *} \\
(6.5-11.1)\end{array}$ & $\begin{array}{c}11.2 \\
(7.1-12.4)\end{array}$ & $\begin{array}{c}11.5 \\
(8.9-15.8)\end{array}$ & $\begin{array}{c}10.9^{* * *} \\
(7.7-13.8)\end{array}$ & $\begin{array}{c}9.0^{\star * *} \\
(4.8-11.4)\end{array}$ \\
\hline $\begin{array}{l}\text { Non-affected } \\
\text { testis }\end{array}$ & $\begin{array}{c}18.5 \\
(18.0-19.0)\end{array}$ & $\begin{array}{c}15.0 \\
(12.1-17.5)\end{array}$ & $\begin{array}{c}17.9 \\
(12.3-33.2)\end{array}$ & $\begin{array}{c}15.3 \\
(10.3-18)\end{array}$ & $\begin{array}{c}16.7 \\
(13.4-20)\end{array}$ & $\begin{array}{c}14.0 \\
(11.2-18)\end{array}$ & $\begin{array}{c}12.1 \\
(10.6-21.6)\end{array}$ & $\begin{array}{c}14.6 \\
(11-19.9)\end{array}$ & $\begin{array}{c}15.8 \\
(10-22.9)\end{array}$ \\
\hline Patients & 2 & 5 & 3 & 4 & 20 & 4 & 16 & 30 & 19 \\
\hline
\end{tabular}

${ }^{*}$ ) Only 1 case with data

${ }^{\star} \mathrm{p}<0.05 ;{ }^{* \star} \mathrm{p}<0.01 ;{ }^{* \star *} \mathrm{p}<0.005 ;{ }^{* \star * *} \mathrm{P}<0.001$

tients refused hormone treatment (10 testes). HCG therapy induced the descent of 14 testes (20\%), two of them located inguinal (5.4\%) and 12 pre-scrotal (41.37\%). Descent after hormonal therapy was not noticed in cases of non-palpable testes (6 patients). 10 primary and 56 secondary orchidopexies were made in bilateral cryptorchidism. Of the three non-palpable bilateral cases, a severe atrophic testicle was found during surgical procedure $(3 / 6,50 \%)$. The mean testicular volume of the undescended testes in the bilateral group (12.93 $\mathrm{mL}$ ) was significantly greater than the unilateral group $(9.7 \mathrm{~mL})$. However, this testicular measurement was significantly lower than the normal value for the healthy contralateral testes in unilateral cryptorchidism $(16.2 \mathrm{~mL})$. The hormone levels were within normal ranges in all bilateral patients except in six cases. Mean hormonal values in bilateral cases were $11.28 \mathrm{IU} / \mathrm{L}$ for FSH, $4.83 \mathrm{IU} / \mathrm{L}$ for $\mathrm{LH}$ and $5.73 \mathrm{ng} / \mathrm{mL}$ for testosterone.
The mean volume of the 14 testes that descended after treatment with HCG $(14.4 \mathrm{~mL})$ was significantly greater than the non-responders group $(11.1 \mathrm{~mL})$ or even than the group of patients who underwent orchidopexy without previous hormonal therapy $(11.4 \mathrm{~mL})$. A significant reduction in testicular size was noticed in cases of non-palpable bilateral testis $(10.4 \mathrm{~mL})$ in respect to palpable ones $(12.4 \mathrm{~mL})$. In these particular patients with bilateral criptorchidism and non-palpable testes, the FSH levels were significantly lower in relation to palpable cases (15.6 vs $10.4 \mathrm{IU} / \mathrm{L})$. Similar results were obtained with $\mathrm{LH}$ levels (6.7 vs $4.4 \mathrm{IU} / \mathrm{L}$ ) and Testosterone values (3.7 vs $6.1 \mathrm{ngr} / \mathrm{mL}$ ).

In patients with bilateral cryptorchidism treated before two years of age, we noticed mean testicular volume measurements significantly smaller $(10.3 \mathrm{~mL})$ than those treated after two years $(12.1 \mathrm{~mL})$. Comparing these two separate 
Table 3 - Bilateral cryptorchidism $(n=80)$ Features based on testis location and therapy used (A-only hormonal treatment; B-hormonal first and surgery later; CX - surgery alone).

\begin{tabular}{|c|c|c|c|c|c|c|c|}
\hline & \multicolumn{3}{|c|}{ Pre-Scrotal (34) } & \multicolumn{3}{|c|}{ Inguinal (40) } & \multirow{3}{*}{$\begin{array}{c}\text { Non-Palpable (6) } \\
\text { Treatment } \\
\text { B }\end{array}$} \\
\hline & \multicolumn{2}{|c|}{ Hormonal Therapy } & \multirow[t]{2}{*}{$c X$} & \multicolumn{2}{|c|}{ Hormonal Therapy } & \multirow[t]{2}{*}{$c X$} & \\
\hline & $A$ & B & & A & B & & \\
\hline Patients & 12 & 19 & 3 & 2 & 31 & 7 & 6 \\
\hline FSH (UI/L) & 9.2 & 6.6 & 13.9 & - & 5.3 & 17.1 & 15.6 \\
\hline Range & $(3.0-10.8)$ & $(3.5-10.1)$ & $(13.9-22.3)$ & & $(2.3-13.2)$ & $(7.5-19.7)$ & $(15.6-15.6)$ \\
\hline LH (UI/L) & 4.2 & 3.4 & 4.0 & - & 4.8 & 5.9 & 6.7 \\
\hline Range & $(3.1-9.6)$ & $(2.5-4.9)$ & $(4.0-5.9)$ & & $(3.4-7.7)$ & $(4.8-8.8)$ & $(6.7-6.7)$ \\
\hline TEST. (Ng/mL) & 7.5 & 5.6 & $5.9\left(^{*}\right)$ & - & 5.7 & 6.0 & 3.7 \\
\hline Range & $(6.0-8.4)$ & $(5.3-6.4)$ & & & $(5.3-6.6)$ & $(2.5-8.5)$ & $(3.7-3.7)$ \\
\hline Age at Treat. & 96.3 & 109.1 & 114.0 & 29.6 & 82.9 & 100.2 & 55.5 \\
\hline (Months) & $(71.8-102.5)$ & $(61.0-125.7)$ & $(88.6-115.0)$ & $(29.6-29.6)$ & $(30.6-130.0)$ & $(37.1-103.0)$ & $(47.8-127.9)$ \\
\hline Testic. Volume & 15.40 & 12.6 & 11.2 & 13.5 & 10.3 & 11.7 & 10.4 \\
\hline Range & $(10.9-16.7)$ & $(9.0-18.5)$ & $(10.5-12.0)$ & $(12-15.0)$ & $(7.6-14.7)$ & $(5.1-13.1)$ & $(1.8-18.1)$ \\
\hline
\end{tabular}

$\left({ }^{\star}\right)$ Only 1 case with data.

groups of bilateral cases (treated before and after two years of age), hormonal levels were significantly different too: FSH (3.0 vs 9.0 IU/L), LH (5.1 vs $5.5 \mathrm{IU} / \mathrm{L}$ ) and Testosterone (6.5 vs $6.0 \mathrm{ngr} /$ $\mathrm{mL}$ ) (Table-4). Statistical analysis results indicated that the mean volume of undescended testicle showed a strong positive relationship with type of cryptorchidism (unilateral or bilateral). Testicular volume is smaller in unilateral cryptorchidism; however, total testicular volumen is greater in unilateral cases in relation to bilateral patients due to the compensatory effect of the healthy contralateral one. Accurate determination of hormonal levels at 18 years of age in our study also showed a significant elevation of FSH levels in bilateral cryptorchidism $(\mathrm{p}=0.001)$, with slight increase in LH levels. Testosterone values were significantly lower in bilateral patients in relation to unilateral cases. There was statistically significant difference between the two groups.

\section{DISCUSSION}

Since testicular volume plays a definitive role in potential of fertility in young adults, accurate measurement is supposed to be relevant in the follow-up of cryptorchid patients. Testicular volume in otherwise healthy young adults is aproximately $18-20 \mathrm{~mL}(10,21)$. Hypoplasia is considered in those with volume less than $14 \mathrm{~mL}$ $(22,23)$ or those with a difference greater than 3 $\mathrm{mL}$ in relation to the healthy contralateral (24). Volume loss was shown to have progressive deleterious effects on the future fertility status. The minimum testicular size for good fertility is approximately $12 \mathrm{~mL}$ (22). Total testicular volume (ie, sum of the volumes of both testes) of approximately $30 \mathrm{~mL}$ is indicative of normal testicular function. We consider that an accepted normal testicular volume at 18 years of age is $14-16 \mathrm{~mL}$ $(22,24)$. Since approximately $70 \%-80 \%$ of tes- 
Table 4 - Bilateral cryptorchidism $(n=80)$ Features based on age and therapy (A-only hormonal treatment; B-hormonal first and surgery later; CX - surgery alone; TEST- testosterone).

\begin{tabular}{|c|c|c|c|c|c|c|c|}
\hline \multirow{3}{*}{$\begin{array}{l}\text { AGE } \\
\text { Groups }\end{array}$} & \multirow{3}{*}{$\begin{array}{c}<2 \text { years } \\
\text { Treatment } \\
\text { B }\end{array}$} & \multicolumn{2}{|c|}{$2-6$ years } & \multicolumn{4}{|c|}{$>6$ years } \\
\hline & & \multicolumn{2}{|c|}{ Treatment } & \multirow[t]{2}{*}{$c x$} & \multicolumn{2}{|c|}{ Treatment } & \multirow[t]{2}{*}{$c X$} \\
\hline & & $A$ & B & & $A$ & B & \\
\hline FSH (UI/L) & 3.7 & 2.8 & 9.5 & - & 10.6 & 6.6 & 15.5 \\
\hline Range & $(1.9-6.3)$ & $(2.5-3.2)$ & $(5.0-15.6)$ & & $(9.2-11.3)$ & $(3.5-11.3)$ & $(9.1-21.0)$ \\
\hline LH (UI/L) & 5.1 & 10.4 & 4.6 & - & 3.3 & 3.8 & 5.3 \\
\hline Range & $(4.3-5.7)$ & $(4.2-16.7)$ & $(2.7-7.2)$ & & $(2.4-7.2)$ & $(2.8-7.9)$ & $(4.2-8.1)$ \\
\hline TEST. ( $\mathrm{Ng} / \mathrm{mL})$ & 6.5 & 6.1 & 5.4 & $5.9\left(^{*}\right)$ & 7.5 & 5.6 & 5.8 \\
\hline Range & $(4.0-6.6)$ & $(4.4-7.9)$ & $(4.1-6.3)$ & & $(6.6-9.8)$ & $(5.3-5.9)$ & $(2.5-8.5)$ \\
\hline Age at Treat. & 20.4 & 43.7 & 47.4 & 37.0 & 100.5 & 119.5 & 101.6 \\
\hline (Months) & $(16.1-23.4)$ & $(29.6-71.8)$ & $(33.6-61.0)$ & $(36.9-37.2)$ & $(95.3-111.3)$ & $(92.4-139.8)$ & $(91.5-112.2)$ \\
\hline Testic Volume & 10.3 & 15.0 & 10.3 & 6.6 & 13.9 & 12.1 & 14.5 \\
\hline Range & $(7.4-18.9)$ & $(12.4-16.1)$ & $(6.6-19.6)$ & $(1.2-12.1)$ & $(10.0-17.2)$ & $(8.8-15.4)$ & $(6.7-12.8)$ \\
\hline Patients & 7 & 6 & 15 & 2 & 8 & 34 & 8 \\
\hline
\end{tabular}

$\left(^{\star}\right)$ Only 1 case with data

ticular mass consists of seminiferous tubules, testicular volume is largely a reflection of spermatogenesis $(23,25-27)$. The testicular volume has been one of the most important endpoints predicting the outcomes of cryptorchid patients related to spermatogenesis. Since it is not usually possible to perform semen analysis in pediatric age group and established clinical criteria to properly define the favourable outcomes are absent, the improvement in the testicular volume has been considered to be the most relevant indirect measure for potential of fertility in adolescents patients $(28,29)$.

Vast majority of authors reported a significant decrease in testicular volume in cryptorchid patients $(10,24,30-33)$, more evident in high locations (30) and in patients treated later during childhood (33). However its not clear if age at referral of hormonal therapy can achieve an improvement in testicular size $(33,34,36-38)$.

According with other authors $(39,40)$ our results showed a marked decrease in the volume of the cryptorchid testis related to the healthy contralateral in unilateral cases. Our rate of testicular volume loss in respect to healthy contralateral in unilateral cases is $34.76 \%$ and in bilateral patients is $23 \%$; both are similar of the percentages refered by other studies (24). Although we have used the contralateral healthy testis as a control, it would be interesting for future studies to include a real control group of normal age-matched adults to compare both hormone levels and testicular volume.

Since the location of the testicle before treatment is strongly related to the ipsilateral testicular volume catch-up growth rate at 18 years of age, our results showing an improvement in size after hormonal therapy on both unilateral and bilateral groups are consistent with those reflected in the reviewed literature due to the more caudal location of these testes (3). This volume catch-up growth rate depends on location before treatment but is not related to the type of therapy employed. Likewise, the lower catch-up growth rate of non-palpable testis at 18 years of age may be explained by the high location inherent to these testicles, and is 
non-related to the treatment modality. However, in unilateral cryptorchidism there is a remarkable improvement in the contralateral testis growth and there are no differences in the total testicular volume in relation to the bilateral group.

However, some authors underestimated the correlation of testicular volume with sperm count of semen profiles (41). According with others, we think that testicular volume had the strongest positive correlation with sperm density, followed in decreasing order by total sperm count per ejaculate, total motile sperm count per ejaculate, and percentage of motile sperm (24).

Likewise, the benefit of early treatment or adjuvant hormonal treatment does not seem clear $(10,42,43)$. Our study showed that in patients with unilateral cryptorchidism treated before 2 years of age, testicular growth was markedly higher for both the undescended testis and the healthy contralateral, compared with those treated after 2 years of age. In bilateral cryptorchidism, by contrast, there is a decrease in catch-up growth testicular rate in the group of patients treated early. Furthermore, these growth differences do not reflect changes in hormone levels at 18 years of age in both age groups (treated before and after two years). Nevertheless, the small number of cases treated before two years of age may influence our statistics workup. Anyway, in the group of patients with unilateral criptorchidism, the early treatment (before two years of age) had a markedly improvement in testicular growth in relation to those treated later. Although animal studies have confirmed the positive effect of early orchiopexy in bilateral cryptorchidism and the little benefit of additional hormone therapy (44), we didn't find these results in our series.

One of the relevant findings of our study is that hormonal treatment before surgery does not appear to exert any beneficial effect in testicular growth at 18 years of age. There are no significant differences in cath-up growth testicular rate and hormone levels between patients undergoing primary surgery and those who were operated on after hormonal treatment failure. We found a significant improvement in testicular size in patients whose testes descended with HCG treatment alone.

Some authors have reported a weak correlation between testicular size at orchiopexy, and lower ratios of paternity, hormone levels, sperm count and testicular volume in adult patients $(45,46)$. According with others, we found a strong positive correlation between lower FSH levels (a marker of spermatogenesis) and high location of the testicle $(9,47,48)$.

We didn't find a direct relationship between testicular volume of the undescended testes and hormone levels in patients at 18 years of age. However, we noticed that in bilateral cryptorchidism, FSH levels were significantly higher than in unilateral patients, despite having the larger volume of the healthy contralateral testes and equal total testicular volume. A possible explanation theory is that there are embryologic and etiopathogenic differences between the unilateral and bilateral criptorchidism (49-51). Anyway, what seems evident is that with only one testicle located in scrotum, the potential of fertility may be preserved (52).

\section{CONCLUSIONS}

In conclusion, the current study shows that the testicular volume and hormonal function at 18 years of age for patients diagnosed and treated for cryptorchidism during childhood are positively and strongly influenced by whether the undescended testis was unilateral or bilateral. Location of the testes at diagnosis or age of initial treatment exerts no definite effect on testicular volume improvement or hormonal levels at 18 years of age.

\section{CONFLICT OF INTEREST}

None declared.

\section{REFERENCES}

1. Virtanen HE, Toppari J: Epidemiology and pathogenesis of cryptorchidism. Hum Reprod Update. 2008;14: 49-58.

2. La Vignera $S$, Calogero $A E$, Condorelli R, Marziani A, Cannizzaro MA, Lanzafame F, et al.: Cryptorchidism and its Iong-term complications. Eur Rev Med Pharmacol Sci. 2009; 13: 351-6. 
3. Mathers MJ, Sperling H, Rübben H, Roth S: The undescended testis: diagnosis, treatment and long-term consequences. Dtsch Arztebl Int. 2009; 106: 527-32.

4. Ritzén EM: Undescended testes: a consensus on management. Eur J Endocrinol. 2008; 159 (Suppl 1): S87-90.

5. Kaplan GW: The undescended testis: changes over the past several decades. BJU Int. 2003; 92 (Suppl 1):12-4.

6. Mengel W, Hienz HA, Sippe WG 2nd, Hecker WC: Studies on cryptorchidism: a comparison of histological findings in the germinative epithelium before and after the second year of life. J Pediatr Surg. 1974; 9: 445-50.

7. Huff DS, Fenig DM, Canning DA, Carr MG, Zderic SA, Snyder HM 3rd: Abnormal germ cell development in cryptorchidism. Horm Res. 2001; 55: 11-7.

8. Ashley RA, Barthold JS, Kolon TF: Cryptorchidism: pathogenesis, diagnosis, treatment and prognosis. Urol Clin North Am. 2010; 37: 183-93.

9. Trsinar B, Muravec UR: Fertility potential after unilateral and bilateral orchidopexy for cryptorchidism. World J Urol. 2009; 27: 513-9.

10. Taskinen S, Wikström S: Effect of age at operation, location of testis and preoperative hormonal treatment on testicular growth after cryptorchidism. J Urol. 1997; 158: 471-3.

11. Anderson RA, Wallace EM, Groome NP, Bellis AJ, Wu FC: Physiological relationships between inhibin $B$, follicle stimulating hormone secretion and spermatogenesis in normal men and response to gonadotrophin suppression by exogenous testosterone. Hum Reprod. 1997; 12: 746-51.

12. Hunter W. State of the testis in the foetus and on the hernia congenita. William Hunter's Medical Commentaries 1762: 75-89.

13. Amann RP, Veeramachaneni DN: Cryptorchidism in common eutherian mammals. Reproduction. 2007; 133: 541-61.

14. Toppari J, Virtanen HE, Main KM, Skakkebaek NE: Cryptorchidism and hypospadias as a sign of testicular dysgenesis syndrome (TDS): environmental connection. Birth Defects Res A Clin Mol Teratol. 2010; 88: 910-9.

15. Queizán de la Fuente A, Nistal Martín de Serrano M: Contribution to the study and treatment of cryptorchism. Cir Pediatr. 1989; 2: 157-67.

16. Wilson-Storey D, McGenity K, Dickson JA: Orchidopexy: the younger the better? J R Coll Surg Edinb. 1990; 35: 362-4.

17. Riebel T, Herrmann C, Wit J, Sellin S: Ultrasonographic late results after surgically treated cryptorchidism. Pediatr Radiol. 2000; 30: 151-5.

18. Sakamoto H, Saito K, Ogawa Y, Yoshida H: Testicular volume measurements using Prader orchidometer versus ultrasonography in patients with infertility. Urology. 2007; 69: 158-62.

19. [No Authors] International Health Foundation. Recommendations pour le traitement de la cryptorchidie. Ann Chir Infant. 1975;16:151-2.
20. Schoemaker J. Uber Kryptorchismus und seine behandlung. Chirurg 1932; 4: 1-3.

21. Bahk JY, Jung JH, Jin LM, Min SK: Cut-off value of testes volume in young adults and correlation among testes volume, body mass index, hormonal level, and seminal profiles. Urology. 2010; 75: 1318-23.

22. Chipkevitch E: Clinical assessment of sexual maturation in adolescents. J Pediatr (Rio J). 2001; 77 (Suppl 2): S135-42.

23. Takihara H, Cosentino MJ, Sakatoku J, Cockett AT: Significance of testicular size measurement in andrology: II. Correlation of testicular size with testicular function. J Urol. 1987; 137: 416-9.

24. Lenz S, Giwercman A, Elsborg A, Cohr KH, Jelnes JE, Carlsen $\mathrm{E}$, et al.: Ultrasonic testicular texture and size in 444 men from the general population: correlation to semen quality. Eur Urol. 1993; 24: 231-8.

25. Vinardi S, Magro P, Manenti M, Lala R, Costantino S, Cortese MG, et al.: Testicular function in men treated in childhood for undescended testes. J Pediatr Surg. 2001; 36: 385-8.

26. Sakamoto $H$, Ogawa $Y$, Yoshida $H$ : Relationship between testicular volume and testicular function: comparison of the Prader orchidometric and ultrasonographic measurements in patients with infertility. Asian J Androl. 2008; 10: 319-24.

27. Arai T, Kitahara S, Horiuchi S, Sumi S, Yoshida K: Relationship of testicular volume to semen profiles and serum hormone concentrations in infertile Japanese males. Int J Fertil Womens Med. 1998; 43: 40-7.

28. Karaman MI, Kaya C, Caskurlu T, Guney S, Ergenekon E: Measurement of pediatric testicular volume with Prader orchidometer: comparison of different hands. Pediatr Surg Int. 2005; 21: 517-20.

29. Taskinen S, Taavitsainen M, Wikström S: Measurement of testicular volume: comparison of 3 different methods. J Urol. 1996; 155: 930-3.

30. Puri P, Sparnon A: Relationship of primary site of testis to final testicular size in cryptorchid patients. Br J Urol. 1990; 66: 208-10.

31. Ku JH, Kim ME, Lee NK, Park YH: Testicular volume and masculine identity in men with unilateral cryptorchidism: results of a community-based survey in Korea. Urol Res. 2003; 31: 312-6.

32. Sijstermans K, Hack WW, van der Voort-Doedens LM, Meijer RW: Long-term testicular growth and position after orchidopexy for congenital undescended testis. Urol Int. 2009; 83: 438-45.

33. Kim SO, Hwang EC, Hwang IS, Oh KJ, Jung SI, Kang TW, et al.: Testicular catch up growth: the impact of orchiopexy age. Urology. 2011; 78: 886-9.

34. Hussain Taqvi SR, Akhtar J, Batool T, Tabassum R, Mirza $\mathrm{F}$ : Correlation of the size of undescended testis with its locations in vatrious age groups. J Coll Physicians Surg Pak. 2006; 16: 594-7. 
35. Michikawa T, Matsufuji H, Araki Y, Nakamura A: Does early orchidopexy prevent morphological changes in undescended testes? A perioperative assessment using ultrasonography. Urol Int. 2008; 81: 210-4.

36. Kollin C, Karpe B, Hesser U, Granholm T, Ritzén EM: Surgical treatment of unilaterally undescended testes: testicular growth after randomization to orchiopexy at age 9 months or 3 years. J Urol. 2007; 178: 1589-93; discussion 1593.

37. Kollin C, Hesser U, Ritzén EM, Karpe B: Testicular growth from birth to two years of age, and the effect of orchidopexy at age nine months: a randomized, controlled study. Acta Paediatr. 2006; 95: 318-24.

38. Murphy F, Paran TS, Puri P: Orchidopexy and its impact on fertility. Pediatr Surg Int. 2007; 23: 625-32.

39. Lenz S, Giwercman A, Elsborg A, Cohr KH, Jelnes JE, Carlsen $E$, et al.: Ultrasonic testicular texture and size in 444 men from the general population: correlation to semen quality. Eur Urol. 1993; 24: 231-8.

40. Kuzanski W, Niedzielski J. Long-term results of surgical treatment of cryptorchid boys. Part I: Testicular volume and risk of malignant transformation. Urologia Polska 2004;57:4.

41. Lee PA: Fertility in cryptorchidism. Does treatment make a difference? Endocrinol Metab Clin North Am. 1993; 22: 47990.

42. Noh PH, Cooper CS, Snyder HM 3rd, Zderic SA, Canning DA, Huff DS: Testicular volume does not predict germ cell count in patients with cryptorchidism. J Urol. 2000; 163: 593-6.

43. Chilvers C, Dudley NE, Gough MH, Jackson MB, Pike MC: Undescended testis: the effect of treatment on subsequent risk of subfertility and malignancy. J Pediatr Surg. 1986; 21 : 691-6.

44. Friedman RM, López FJ, Tucker JA, King LR, Negro-Vilar A: Fertility after cryptorchidism: a comparative analysis of early orchidopexy with and without concomitant hormonal therapy in the young male rat. J Urol. 1994; 151: 227-33.

45. Kamisawa H, Kojima Y, Hayashi Y, Imura M, Mizuno K, et al.: Evaluation of preoperative testicular volume in Japanese children with unilateral cryptorchidism. Int Urol Nephrol. 2008; 40: 977-81.
46. Lee PA, Coughlin MT, Bellinger MF: No relationship of testicular size at orchiopexy with fertility in men who previously had unilateral cryptorchidism. J Urol. 20011; 166: 236-9.

47. Gracia J, Sánchez Zalabardo J, Sánchez García J, García C, Ferrández A: Clinical, physical, sperm and hormonal data in 251 adults operated on for cryptorchidism in childhood. BJU Int. 2000; 85: 1100-3.

48. Absalan F, Movahedin M, Mowla SJ: Spermatogonial stem cell transplantation and subsequent orchidopexy in the bilateral cryptorchid mouse model. Cell J. 2011 Fall; 13: 143-8.

49. Kurokawa S, Kojima Y, Mizuno K, Nakane A, Hayashi Y, Kohri $\mathrm{K}$ : Effect of epidermal growth factor on spermatogenesis in the cryptorchid rat. J Urol. 2005; 174: 2415-9.

50. Schwentner C, Oswald J, Kreczy A, Lunacek A, Bartsch $G$, Deibl M, et al.: Neoadjuvant gonadotropin-releasing hormone therapy before surgery may improve the fertility index in undescended testes: a prospective randomized trial. J Urol. 2005; 173: 974-7.

51. Kojima Y, Hayashi Y, Mizuno K, Kurokawa S, Nakane A, Maruyama $T$, et al.: Future treatment strategies for cryptorchidism to improve spermatogenesis. Hinyokika Kiyo. 2007; 53: 517-22.

52. Ludwikowski B, González R: The controversy regarding the need for hormonal treatment in boys with unilateral cryptorchidism goes on: a review of the literature. Eur $\mathrm{J}$ Pediatr. 2013; 172: 5-8.

Correspondence address: Roberto Méndez-Gallart, MD, PhD Department of Pediatric Surgery \& Urology Hospital Clinico Universitario de Santiago Travesia Choupana $\mathrm{s} / \mathrm{n}$ 15706. Santiago de Compostela. Spain Fax: +34 9 8195-0134

E-Mail: roberto.mendez.gallart@sergas.es 